\title{
The Vaccine and Cervical Cancer Screen (VACCS) project: Linking cervical cancer screening to HPV vaccination in the South-West District of Tshwane, Gauteng, South Africa
}

\author{
L C Snyman, ${ }^{1}$ MB ChB, MPraxMed, MMed (O\&G), FCOG (SA); G Dreyer, ${ }^{1}$ MB ChB, MMed (O\&G), MCOG (SA), PhD; \\ M H Botha, ${ }^{2} \mathrm{MB}$ ChB, MMed (O\&G), FCOG (SA), PhD; F H van der Merwe, ${ }^{2}$ MB ChB, MMed (O\&G), FCOG; \\ P J Becker, ${ }^{1,3} \mathrm{BSc}$ (Hons), MSc, PhD \\ ${ }^{1}$ Department of Obstetrics and Gynaecology and Gynaecological Oncology Unit, Faculty of Health Sciences, University of Pretoria, South Africa \\ ${ }^{2}$ Department of Obstetrics and Gynaecology and Unit for Gynaecological Oncology, Faculty of Medicine and Health Sciences, Stellenbosch \\ University, Tygerberg, Cape Town, South Africa \\ ${ }^{3}$ Biostatistics Unit, South African Medical Research Council, Pretoria, South Africa
}

Corresponding author: L C Snyman (leon.snyman@up.ac.za)

\begin{abstract}
Background. Cervical cancer is preventable, but still highly prevalent in South Africa (SA). Screening strategies in the country have been ineffective, and new ways to prevent the disease are needed.

Objectives. To investigate the feasibility of linking cervical cancer screening in adult women to human papillomavirus (HPV) vaccination in schoolgirls.

Methods. Ten primary schools in the South-West District of Tshwane, Gauteng Province, SA, took part in the study. Cervical cancer and HPV vaccine information was provided to schoolgirls and their parents. Consented schoolgirls were vaccinated and their female parents were invited to participate in self-screening.

Results. Among 1654 girls invited for vaccination, the consented and invited uptake rates were $99.4 \%$ and $64.0 \%$, respectively. Vaccine completion rates were higher in schools where the vaccination programme was completed in the same calendar year than in those where it was administered over two calendar years. Of 569 adult females invited, 253 (44.5\%) returned screen tests; 169 (66.8\%) tested negative and 75 (29.6\%) positive for any high-risk HPV (hrHPV). There were no differences in level of education, employment status or access to healthcare between women with positive and those with negative screen results.

Conclusions. Implementation of HPV vaccination in a primary school-based programme was successful, with high vaccine uptake and completion rates. Self-screening reached the ideal target group, and it is possible to link cervical cancer screening to the cervical cancer vaccine by giving women the opportunity of self-sampling for hrHPV testing. This is a novel and feasible approach that would require some adaptive strategies.

S Afr Med J 2015;105(2):115-120. DOI:10.7196/SAMJ.8418
\end{abstract}

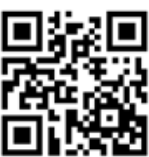

Secondary population-based cervical cancer screening has not been implemented successfully in resourcepoor settings or developing countries anywhere in the world. ${ }^{[1]}$ Reasons for this failure include the difficulties of conventional cytology screening and the fact that many prerequisites need to be in place and functioning well for population-based screening to be implemented; if any one of the components fails to deliver, the whole screening programme fails. ${ }^{[2]}$

Cervical cancer screening in South Africa (SA) is mainly opportunistic, and although the National Department of Health has a cervical cancer screening policy, it has not been implemented at any level. Opportunistic screening tends to over-screen some sub-populations, while many others do not take part. In addition, the main target groups are often not well represented, including age and sociodemographic groups. ${ }^{[3,4]}$ In SA, the communication of results and follow-up of screen-positive women are known to be very problematic. Consequently, the incidence of cervical cancer remains high and the majority of women who are diagnosed present with advanced-stage disease.

To improve screening efforts in SA, new approaches to screening need to investigate improvements in uptake, inclusion of the correct target population, and successful communication of results.

Primary prevention of cervical cancer is now possible with the availability of human papillomavirus (HPV) vaccines targeting HPV types 16 and 18, which cause the majority of cervical cancers worldwide, as well as in Africa. ${ }^{[5]}$ The target population for primary prevention is initially girls between the ages of 9 and 11 years attending primary school. The Vaccine and Cervical Cancer Screen (VACCS) project was a cervical cancer vaccine implementation study, which also provided the opportunity to investigate the outcome of cervical cancer screening when linked to the vaccination of schoolgirls. Potential advantages of this approach are the linking of two relevant, but different, health interventions aimed at cervical cancer prevention and the possibility of exploiting the educational and logistic opportunities inherent to school-based programmes. In addition, this project utilised new molecular screening technology that offered the opportunity to use self-sampling in a home setting.

\section{Methods}

This was a national study conducted in Gauteng and Western Cape provinces, SA, with the approval of the national and provincial departments of Basic Education and Health. The study methodology differed slightly between the two provinces, and in this report the method and results of the Gauteng arm of the study are described.

In Gauteng, ten primary schools were identified in Atteridgeville and the South-West District of Tshwane. After obtaining consent from the governing body and principal of each school, information events were held at the schools during 2011 and 2012. All the girls in grades $4-7$ and their female parents or guardians were invited to attend these events. 
During the information event, attending female parents and guardians were interviewed and completed questionnaires (Appendix 1, available in the online version of this article), after which they attended a session at which information on cervical cancer, the vaccine for primary prevention and screening for the disease was provided by a medical doctor in the form of a 15-minute PowerPoint presentation as well as through the distribution of information leaflets in English or Tswana. During the vaccination programme, telephonic interviews were conducted, repeating the questions that tested knowledge and screening behaviour (Appendix 1, available in the online version of this article).

Female parents and guardians attending the information events were invited to take part in self-administered HPV screening and to take a screen kit for themselves as well as for a friend or family member. The screen kit consisted of a tampon with user instructions; women were to insert the tampon vaginally and remove it after one hour. The used tampon was placed in a container with buffer and, together with personal information, returned to the school in a sealed envelope. DNA was extracted from the tampon specimens and tested using Roche linear array for HPV DNA testing as described previously. ${ }^{[6]}$

Parents and guardians of girls aged 9 years and older in grades 4 - 7 were invited to provide consent, and all girls were requested to provide consent for HPV vaccination. The vaccine was administered per protocol by a team of registered nurses during school hours. Both bivalent and quadrivalent vaccines donated by the manufacturing companies were available to be administered.
The ages and previous screening histories of women who accepted the invitation to screen were determined to assess whether an appropriate target population for secondary prevention was reached. HPV test results were interpreted as positive if DNA of any of the 15 high-risk viral types $(16,18,31,33,35,39,45,51,52,56,58,59,68,73,82)$ were demonstrated, and as invalid if no DNA amplification occurred as tested by the internal control. Women testing positive for the two most oncogenic HPV types (16 and 18) were reported separately.

\section{Definitions}

The invited cohort (IC) was defined as all female learners enrolled in the selected schools in grades $4-7$. The consented cohort (CC) was defined as participants with written consent and assent from the learner. Girls with consent whose parents or guardians did not attend vaccine events were included in the CC. The vaccinated cohort (VC) was defined as all girls who received one vaccine dose. Vaccine uptake rates were calculated in a number of ways in order to allow comparison with other published HPV vaccine reports. The consented uptake rate (CUR) was calculated as $\mathrm{VC} / \mathrm{CC}$, with the invited uptake rate (IUR) calculated as VC/IC

Vaccine completion was calculated using the vaccinated cohort as denominator. The vaccine completion rate (VCR) was calculated using all girls who received all three vaccine doses. Girls who received only two vaccine doses within a short period of time were then separated from those who received the two vaccines at least 6 months apart, and the latter group was considered sufficiently vaccinated based on recent data suggesting protective antibody levels against vaccine HPV

Table 1. Uptake, vaccination and completion rates in schools vaccinated over one and two calendar years

\begin{tabular}{l|l|l|l|l|l|l|l|l|l}
\hline & IC & CC & VC & Single dose & $\begin{array}{l}\text { Doses 1 } \\
\text { and 2 }\end{array}$ & $\begin{array}{l}\text { Doses 2 } \\
\text { and 3 }\end{array}$ & Doses 1 and 3 & All 3 doses & $\begin{array}{l}\text { Doses 1 and 3, } \\
+/ \text { - dose 2 }\end{array}$ \\
\hline & All girls & $\begin{array}{l}\text { All girls } \\
\text { with } \\
\text { consent } \\
\text { and assent }\end{array}$ & $\begin{array}{l}\text { Received } \\
\text { at least } \\
\text { one dose }\end{array}$ & $\begin{array}{l}\text { Received } \\
\text { only 1 } \\
\text { vaccine } \\
\text { dosage }\end{array}$ & $\begin{array}{l}\text { Received } \\
\text { 2 doses, 6 } \\
\text { weeks apart }\end{array}$ & $\begin{array}{l}\text { Received } \\
2 \text { doses, } \\
<6 \text { months } \\
\text { apart }\end{array}$ & $\begin{array}{l}\text { Received 2 } \\
\text { dosages, 6 } \\
\text { months apart }\end{array}$ & $\begin{array}{l}\text { Received } \\
\text { all 3 doses }\end{array}$ & $\begin{array}{l}\text { Received at } \\
\text { least 2 doses, } \\
\text { min. 6 months } \\
\text { apart }\end{array}$ \\
\hline
\end{tabular}

Three vaccine doses administered within one calendar year: eight schools

\begin{tabular}{|c|c|c|c|c|c|c|c|c|c|}
\hline $\mathrm{B} 1$ & 61 & 54 & 54 & 0 & 1 & 0 & 0 & 53 & 53 \\
\hline B2 & 87 & 79 & 79 & 2 & 3 & 0 & 1 & 74 & 75 \\
\hline B3 & 183 & 118 & 119 & 1 & 1 & 3 & 6 & 108 & 114 \\
\hline B4 & 223 & 127 & 127 & 0 & 3 & 4 & 3 & 117 & 120 \\
\hline B6 & 123 & 59 & 59 & 1 & 1 & 3 & 7 & 47 & 54 \\
\hline B7 & 166 & 70 & 70 & 1 & 5 & 1 & 2 & 61 & 63 \\
\hline B8 & 181 & 136 & 136 & 0 & 1 & 4 & 0 & 131 & 131 \\
\hline B9 & 155 & 99 & 95 & 3 & 0 & 3 & 40 & 48 & 88 \\
\hline Subtotal & 1179 & 742 & 739 & 8 & 15 & 18 & 59 & 639 & 698 \\
\hline Vaccination rates & & IUR $62.9 \%$ & CUR $99.6 \%$ & \multicolumn{3}{|l|}{ IVR $5.5 \%$} & & VCR $86.5 \%$ & SVR $94.5 \%$ \\
\hline \multicolumn{10}{|c|}{ Three vaccine doses administered over two calendar or school years: two schools } \\
\hline B5 & 225 & 159 & 159 & 1 & 43 & 1 & 11 & 103 & 114 \\
\hline $\mathrm{B} 10$ & 250 & 158 & 155 & 0 & 22 & 4 & 1 & 128 & 129 \\
\hline Subtotal & 475 & 317 & 314 & 1 & 65 & 5 & 12 & 231 & 243 \\
\hline Vaccination rates & & IUR $66.7 \%$ & CUR $99.1 \%$ & \multicolumn{3}{|l|}{ IVR $22.6 \%$} & & VCR $73.5 \%$ & SVR $77.4 \%$ \\
\hline \multicolumn{10}{|c|}{ Total Gauteng cohort: ten schools } \\
\hline Total & 1654 & 1059 & 1053 & 9 & 80 & 23 & 71 & 870 & 941 \\
\hline Vaccination rates & & IUR $64.0 \%$ & $\begin{array}{l}\text { CUR } \\
99.4 \%\end{array}$ & IVR $10.6 \%$ & & & & VCR $82.6 \%$ & SVR $89.4 \%$ \\
\hline
\end{tabular}


types in similar recipients. ${ }^{[7,8]}$ The insufficiently vaccinated rate (IVR) was calculated using the number of girls who received only one dose, or two doses $<6$ months apart.

\section{Statistical analysis}

Questionnaire data were obtained from women who participated in the study and consisted of basic demographic data as well as data on access to and use of healthcare facilities. In addition, knowledge about cervical cancer and prevention of the disease was tested before and after the information event. Knowledge scores were calculated by awarding points for correct answers to a maximum score of 5 marks each for symptoms of, screening for and vaccination against cervical cancer. Changes in knowledge as tested by the same questions asked before and after the information event were measured and compared between groups. A $p$-value of $<0.05$ was regarded as statistically significant.

Women who participated in self-screening were compared with a matched control group of women who did not participate. Within the participants of self-screening, data from all women with positive screen results were compared with a matched subgroup of those who screened negative. Matching of both control groups was done using age and the school attended by the child. There were no significant differences with regard to level of education, employment status and access to healthcare between the three groups of women.

The study was approved by the Research Ethics Review Committee of the Faculty of Health Sciences, University of Pretoria (219/2009).

\section{Results \\ Vaccination data}

In the ten schools included in the project, the IC consisted of 1654 girls, of whom 1059 had given full consent (CC); 1053 girls received the first vaccine dose (VC). The CUR was $99.4 \%$ and the IUR $64.0 \%$. In the CC group, 498 parents or guardians provided informed parental consent during the information events held at the different schools, while 561 provided written informed consent on the basis of the information leaflet that learners took home. Five hundred and sixty-nine parents or guardians attended the information events and questionnaire interviews, while 1085 received only leaflet information. Consent for vaccination was therefore provided by 561 of 1085 parents $(51.7 \%)$ who received only leaflet information, and by 498 of 569 (87.5\%) who attended the information events $(p<0.0001)$.

In eight of the ten schools, all three doses of the vaccination were completed in the same calendar year. Vaccine completion rates were superior in these schools compared with the two schools in which vaccination was scheduled over two calendar years. Vaccine uptake and VCRs per school as well as the effect of scheduling over one and two calendar years are shown in Table 1. No serious adverse events related to vaccination were reported.

\section{Screening results}

The 569 female parents or guardians attending the information events at the different schools were invited to take selfscreening kits home. A total of 795 screen tests were handed out, of which 253 (44.5\%) were returned and tested for the presence of high-risk HPV (hrHPV) DNA. The mean age (standard deviation) of the screened population (Fig. 1) was 38.3 (10.2) years (95\% confidence interval 37.0 - 39.6), and the median age was 38.5 years.

Of the 253 samples tested, 9 (3.6\%) were reported as invalid, $169(66.7 \%)$ tested negative for hrHPV and 75 (29.6\%) were positive for any

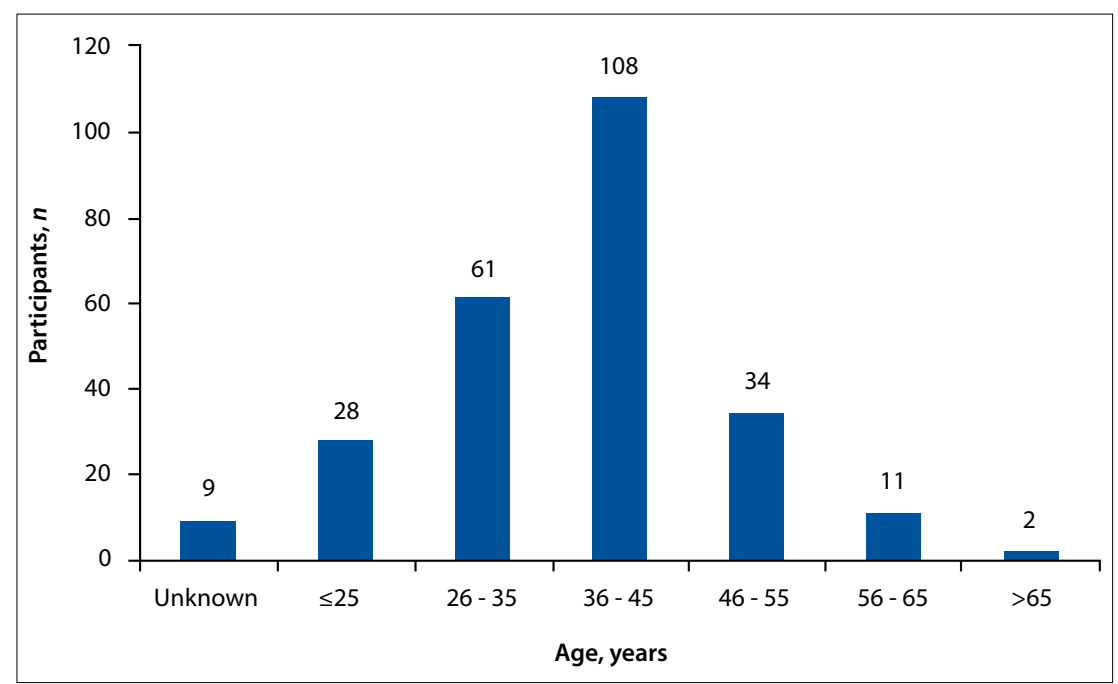

Fig. 1. Age distribution of screened women.

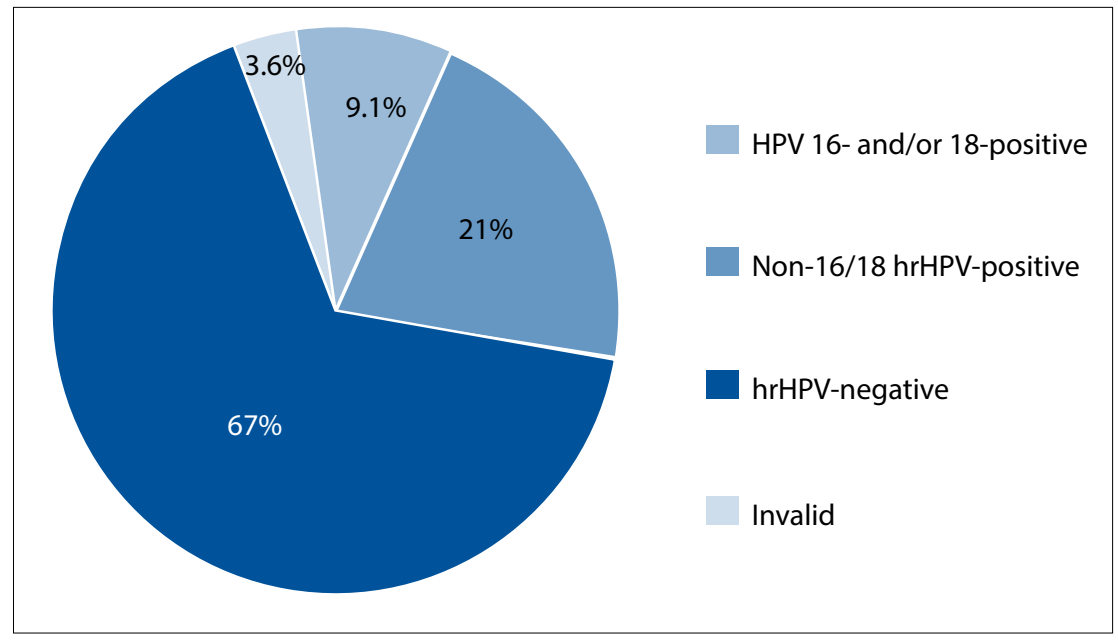

Fig. 2. Molecular results of self-collected cervical screening tests.

hrHPV. The hrHPV results are shown in Fig. 2. Twenty-three samples $(9.1 \%)$ were positive for HPV type 16 and/or 18, and 52 (20.5\%) were positive for one or more of the remaining 13 high-risk types. Of the 75 positive specimens, 43 (57.3\%) had a single type and $32(42.7 \%)$ tested positive for more than one hrHPV.

\section{Cervical cancer knowledge}

Knowledge scores for cervical cancer symptoms, screening and vaccines for the total group before and after the educational intervention are shown in Fig. 3. Initial knowledge of all aspects was insufficient, but improved scores were obtained in the second questionnaire.

Considering the screened and unscreened groups, there was no difference in initial knowledge of cervical cancer and its symptoms, which was poor in both groups. Around 70\% in both groups obtained 0 or 1 out of the potential 5 marks awarded. Among women who participated in self-screening, the level of cervical cancer knowledge improved significantly after the information event $(n=132$;

HPV 16- and/or 18-positiv

Non-16/18 hrHPV-positive

hrHPV-negative

nvalid 


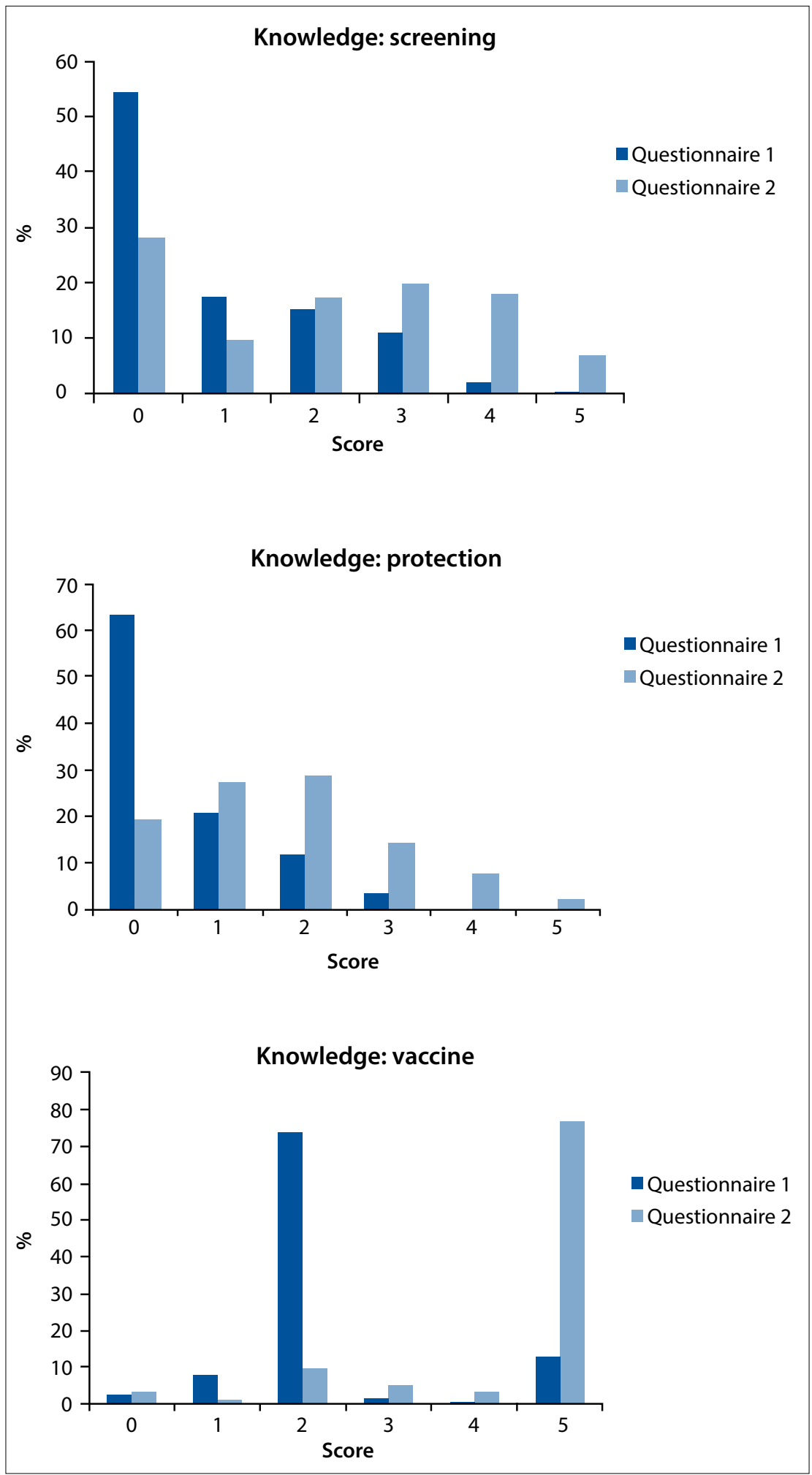

Fig. 3. Improvement in knowledge scores for cervical cancer symptoms, screening and vaccines.

$p<0.001)$ (Table 2), while among unscreened women the improvement was not statistically significant $(n=41 ; p=0.06)$ (Table 2$)$.

With regard to knowledge of cervical cancer prevention, knowledge of screening and vaccination improved significantly after the information event among screened and unscreened groups (data not shown, $p<0.001)$.

\section{Screening behaviour}

Self-reported previous screening behaviour did not differ significantly between women who participated in self-screening compared with those who did not ( $p=0.169$ ); $51.2 \%$ of women who participated in self-screening reported no previous screening ever or did not know whether they had had screening in the past, compared with $48.8 \%$ of non-participants.

It is interesting that after participating in the project, 45 of 131 screened women (34.3\%) reported that their last 'cervical cancer test' was more than 5 years ago. Despite this disparity, there was still a significant improvement in reported screening behaviour in this group between the two questionnaires $(p<0.001)$ (Table 3) compared with the control group, which did not show significant improvement $(p=0.036)$ (Table 3).

\section{Discussion}

Vaccine uptake data differ worldwide and are influenced by numerous social, religious and economic factors. In addition, vaccine programme and communication strategies have a very large effect on uptake. Uptake of HPV vaccines is low in the USA and Germany ${ }^{[9,10]}$ and high in Australia, ${ }^{[11]}$ while uptake rates in Africa vary. ${ }^{[12-14]}$

Vaccine uptake, calculated as the proportion of girls who received one vaccine dose from the total IC, was $64.0 \%$ for the total group in this study. The project protocol allowed for the provision of only sketchy information to prospective participants, because another aim of the study was to test baseline knowledge. Although it can be argued that interested and informed parents were more likely to attend, the relatively low vaccine uptake (51.7\%) among parents who did not attend the information event compared with those who did attend (87.5\%) could probably be attributed in part to this lack of information.

Moodley et al. ${ }^{[15]}$ reported overall HPV vaccine uptake in an implementation study in KwaZulu-Natal Province, SA, of 99.7\%, $97.9 \%$ and $97.8 \%$ for the first, second and third vaccination doses, respectively. These data represent the uptake and completion rates of those who consented, but uptake as a proportion of girls available for vaccination was not provided. In the current study, similar success in vaccination of consented girls of $99.4 \%, 98.6 \%$ and $82.6 \%$ for one, two and all three doses, respectively, was achieved. In addition to uptake and completion rates, the proportion of the $\mathrm{VC}$ that received at least two vaccine doses at least 6 months apart was calculated. To our knowledge it is the first time that HPV vaccine data from an implementation or demonstration project have been presented in this way, and these results therefore cannot be compared.

In a school-based programme, it is acknowledged that VCRs are largely influenced by the number of follow-up visits to 
Table 2. Improved knowledge on cervical cancer and its symptoms (upper triangles of table, above the grey tint) among screened and unscreened women

\begin{tabular}{|c|c|c|c|c|c|c|c|c|}
\hline & \multicolumn{8}{|c|}{ Knowledge about cervical screening: scores after information event } \\
\hline \multicolumn{9}{|l|}{ Screened women ${ }^{*}$} \\
\hline \multirow{8}{*}{$\begin{array}{l}\text { Knowledge about cervical } \\
\text { screening: scores before } \\
\text { information event }\end{array}$} & Score & 0 & 1 & 2 & 3 & 4 & 5 & Total \\
\hline & 0 & 30 & 6 & 11 & 6 & 13 & 6 & 72 \\
\hline & 1 & 4 & 2 & 2 & 6 & 6 & 2 & 22 \\
\hline & 2 & 2 & 2 & 5 & 8 & 2 & 1 & 20 \\
\hline & 3 & 1 & 0 & 1 & 7 & 3 & 3 & 15 \\
\hline & 4 & 1 & 0 & 0 & 1 & 1 & 0 & 3 \\
\hline & 5 & 0 & 0 & 0 & 0 & 0 & 0 & 0 \\
\hline & Total & 38 & 10 & 19 & 28 & 25 & 12 & 132 \\
\hline \multicolumn{9}{|l|}{ Unscreened women $^{\dagger}$} \\
\hline \multirow{8}{*}{$\begin{array}{l}\text { Knowledge about cervical } \\
\text { screening: scores before } \\
\text { information event }\end{array}$} & Score & 0 & 1 & 2 & 3 & 4 & 5 & Total \\
\hline & 0 & 9 & 2 & 6 & 2 & 0 & 0 & 19 \\
\hline & 1 & 2 & 3 & 3 & 1 & 1 & 0 & 10 \\
\hline & 2 & 0 & 2 & 2 & 2 & 1 & 0 & 7 \\
\hline & 3 & 0 & 0 & 0 & 1 & 3 & 0 & 4 \\
\hline & 4 & 0 & 0 & 0 & 0 & 1 & 0 & 1 \\
\hline & 5 & 0 & 0 & 0 & 0 & 0 & 0 & 0 \\
\hline & Total & 11 & 7 & 11 & 6 & 6 & 0 & 41 \\
\hline
\end{tabular}

Table 3. Improvement in self-reported screening behaviour (upper triangles of table, above the grey tint) among screened women but not among unscreened women

Self-reported screening behaviour after intervention

Screened women*

Self-reported screening Score behaviour before 0

intervention

33

$\begin{array}{lll}0 & 1 & 2 \\ 33 & 4 & 1 \\ 0 & 0 & 0 \\ 0 & 0 & 0 \\ 1 & 0 & 0 \\ 2 & 0 & 0 \\ 0 & 0 & 0 \\ 36 & 4 & 1\end{array}$

Unscreened women

Self-reported screening Score behaviour before 0 intervention

0
1
2
3
4
5
Total

$\begin{array}{lll}0 & 1 & 2 \\ 11 & 2 & 0 \\ 0 & 0 & 0 \\ 0 & 0 & 0 \\ 0 & 0 & 0 \\ 0 & 0 & 2 \\ 0 & 0 & 0 \\ 11 & 2 & 2\end{array}$

Scores: $0=$ never; $1=$ don't know; $2=>10$ years ago; $3=6-10$ years ago; $4=1-5$ years ago; $5=<1$ year ago. ${ }^{*} p<0.001$

$p=0.036$.

the school. In an attempt to simulate large-scale rollout of schoolbased vaccination, extra follow-up visits to schools where unforeseen school activities and absenteeism prevented a large number of girls from attending scheduled vaccination were limited to one. In view 
of this limited effort to improve vaccine completion, the attained VCR of $82.6 \%$ and a sufficiently vaccinated rate (SVR) of $89.4 \%$ are considered very satisfactory.

Vaccination in a single calendar year was more successful than vaccination scheduled over two years, as reflected by better VCRs $(86.5 \%$ v. $73.5 \%)$ and SVRs $(94.5 \%$ v. $77.4 \%)$. The difference can possibly be attributed to the December holiday break, children changing schools and promotion to secondary schools, which resulted in fewer girls receiving the important third dose. Although not surprising, this is to our knowledge the first confirmation of this effect reported from SA. The projected large loss of immune response and resulting herd immunity caused by an inefficiently vaccinated population is of huge importance for the planning of all vaccine rollout programmes using school-based infrastructure.

Screening uptake, calculated as the proportion of women screened from those invited, was $44.5 \%$ in this study. Furthermore, in this study 253 women took up screening, of whom more than half reported no previous cervical cancer screening. Molecular screening results identified cervical cancer risk in $28.8 \%$ and a high risk for future disease in $9.1 \%$. Using the school infrastructure as well as mobile phone technology, all women received screen results and this was confirmed for all screen-positive women.

All five of these parameters compare favourably to the limited data available for the existing cytology-based countrywide screening programme. According to the World Health Organization, cervical cytology coverage of eligible women in SA for the period 2000 - 2006 was estimated to be $17 \%{ }^{[16]}$ Screening will have the largest effect on cancer incidence if coverage is large, the correct high-risk target group is reached, and the biggest possible number of screen-positive women can get results and receive preventive therapy. HPV screening in low-resource settings is feasible, and self-sampling offers the added benefits of eliminating a clinic visit, speculum examination and the need for a healthcare provider to perform screening.

In addition to screening, education about cervical cancer symptoms and screening was successfully linked to the cervical cancer vaccine by the provision of information to parents or guardians of girls invited to be vaccinated. Knowledge about cervical cancer-related matters was lacking in this group of urban mothers, but improved following the provision of information. Neither demographics nor baseline knowledge predicted screening uptake in this study. Positive screening behaviour was associated with an improvement in knowledge about cervical cancer. As expected, most screening participants reported an improvement in screening behaviour after the tampon test, reflecting an understanding of the intention of the test. The finding that some women who took part in self-screening were not aware of the fact that they were screened could be attributed to a lack of knowledge or the structure of the questionnaire.

\section{Conclusion}

Implementation of HPV vaccination in a primary school-based programme was hugely successful. No serious adverse events were reported, and uptake rates of $64.0 \%$ of the IC and $99.4 \%$ of the CC were achieved. Vaccine completion was optimal when all vaccine doses were offered within a single calendar year.

Self-screening tests reached the ideal target group, and results were successfully reported to all participants. Linking cervical cancer screening to the cervical cancer vaccine was possible by providing women the opportunity to self-sample. This is a novel approach that would require some adaptive strategies, but was feasible and practical in the setting of this trial.
Knowledge about cervical cancer, its symptoms and prevention is generally poor, and school-based vaccine programmes offer a unique opportunity to provide appropriate information. This report of the Gauteng part of the VACCS project confirmed a measurable improvement in knowledge following health education. In addition, it was demonstrated that improved knowledge correlated with the uptake of screening.

Acknowledgements. The assistance of the following groups and persons that enabled the successful completion of this project is gratefully acknowledged. Financial support was received from the Cancer Research Initiative of South Africa, a national collaborative research programme supported by the South African Medical Research Council and the Cancer Association of South Africa, and First for Women Insurance for screening and treatment of screen-positive women and investigator support. The vaccine manufacturing companies GlaxoSmithKline/Aspen SA and Merck supported this investigator-initiated study by generously donating all vaccines used in this project. Ms Debbie Constant of the School of Public Health, University of Cape Town, assisted with development of the questionnaire, Prof. Gerhard Lindeque provided valuable advice, Ms Bertha Grond managed the finances; Ms Riekie Burden and her team of registered nurses handled study and vaccine processes, Dr Karin Richter managed laboratory screening data, Ms Cathy Visser collated and analysed the vaccination and screening data, consultants and registrars of the Department of Obstetrics and Gynaecology, University of Pretoria, presented lectures at the information events, undergraduate medical students administered the questionnaires, and Ms Barbara English of the Faculty of Health Sciences, University of Pretoria, assisted with language editing.

\section{References}

1. Gakidou E, Nordhagen S, Obermeyer Z. Coverage of cervical cancer screening in 57 countries: Low average levels and large inequalities. PLoS Med 2008;5(6):e132. [http://dx.doi.org/10.1371/journal.pmed.0050132] 2. Richter KL. Understanding and incorporating human papillomavirus testing in cervical cancer screening: A South African perspective. South African Journal of Gynaecological Oncology 2011;3(1):9-14.

Seidel D, Becker N, Rohrmann S, Nimptsch K, Linseisen I. Socio-demographic characteristics of participation Seidel D, Becker N, Rohrmann S, Nimptsch K, Linseisen J.Socio-demographic characteristics of participation
in the opportunistic German cervical cancer screening programme: Results from the EPIC-Heidelberg in the opportunistic German cervical cancer screening programme: Results from the EPIC-Heidel
cohort. J Cancer Res Clin Oncol 2009;135(4):533-541. [http://dx.doi.org/10.1007/s00432-008-0485-0]

cohort. J Cancer Res Clin Oncol 2009;135(4):533-541. [http://dx.doi.org/10.1007//500432-008-0485-0]
4. Freitas RA, Carvasan GA, Morais SS, Zeferino LC. Excessive Pap smears due to opportunistic cervical cancer screening. Eur J Gynaecol Oncol 2008;29(5):479-482.

5. Denny L, Adewole I, Anorlu R, et al. Human papillomavirus prevalence and type distribution in invasive cervical cancer in sub-Saharan Africa. Int J Cancer 2014;134(6):1389-1398. [http://dx.doi.org/10.1002/ijc.28425]

6. Richter K, Becker P, Horton A, Dreyer G. Age-specific prevalence of cervical human papillomavirus infection and cytological abnormalities in women in Gauteng Province. S Afr Med J 2013;103(5):313317. [http://dx.doi.org/10.7196/SAMJ.6514]

7. Dobson SR, McNeil S, Dionne M, et al. Immunogenicity of 2 doses of HPV vaccine in younger adolescents vs 3 doses in young women: A randomized clinical trial. JAMA 2013;309(17):1793-1802 [http://dx.doi.org/10.1001/jama.2013.1625]

8. Lazcano-Ponce E, Stanley M, Munoz N, et al. Overcoming barriers to HPV vaccination: Non-inferiority of Lazcano-Ponce $\mathrm{E}$, Stanley $\mathrm{M}$, Munoz $\mathrm{N}$, et al. Overcoming barriers to $\mathrm{HPV}$ vaccination: Non-inferionity
antibody response to human papillomavirus $16 / 18$ vaccine in adolescents vaccinated with a two-dose vs. a threedose schedule at 21 months. Vaccine 2014;32(6):725-732. [http://dx.doi.org/10.1016/j.vaccine.2013.11.059]

Delere Y, Bohmer MM, Walter D, Wichmann O. HPV vaccination coverage among women aged 18-20 years Delere $\mathrm{Y}$, Bohmer MM, Walter D, Wichmann $\mathrm{O}$. HPV vaccination coverage among women aged 18-20 years
in Germany three years after recommendation of HPV vaccination for adolescent girls: Results from a crossin Germany three years after recommendation of HPV vaccination for adolescent girls: Results from a
sectional survey. Hum Vaccin Immunother 2013;9(8):1706-1711. [http://dx.doi.org/10.4161/hv.24904]

sectional survey. Hum Vaccin Immunother $2013 ; 9(8): 1706-1711$. [http://dx.doi.org/ $10.4161 / \mathrm{hv} .24904]$
10. Dorell C, Yankey D, Jeyarajah J, et al. Delay and refusal of human papillomavirus vaccine for girls, national immunization survey-teen, 2010. Clin Pediatr 2014;53(3):261-269. [http://dx.doi. org/10.1177/0009922813520070

11. Brotherton JM, Murray SL, Hall MA, et al. Human papillomavirus vaccine coverage among female Australian adolescents: Success of the school-based approach. Med J Aust 2013;199(9):614-617 [http://dx.doi.org/10.5694/mja13.10272]

12. Binagwaho A, Wagner CM, Gatera M, Karema C, Nutt CT, Ngabo F. Achieving high coverage in Rwanda's national human papillomavirus vaccination programme. Bull World Health Organ 2012;90(8):623-628. [http://dx.doi.org/10.2471/BLT.11.097253]

13. Jumaan AO, Ghanem S, Taher J, Braikat M, Al Awaidy S, Dbaibo GS. Prospects and challenges in the introduction of human papillomavirus vaccines in the extended Middle East and North Africa region. introduction of human papillomavirus vaccines in the extended Middle East and North

14. Watson-Jones D, Baisley K, Ponsiano R, et al. Human papillomavirus vaccination in Tanzanian schoolgirls: Cluster-randomized trial comparing 2 vaccine-delivery strategies. I Infect Dis schoolgirls: Cluster-randomized trial comparing 2 vacci

15. Moodley I, Tathiah N, Mubaiwa V, Denny L. High uptake of Gardasil vaccine among 9 - 12-yearold schoolgirls participating in an HPV vaccination demonstration project in KwaZulu-Natal, South Africa. S Afr Med J 2013;103(5):318-321. [http://dx.doi.org/10.7196/SAMJ.6414]

16. World Health Organization. World Health Statistics 2008. World Health Organization, 2008. http:// www.who.int/whosis/whostat/EN_WHS08_Full.pdf (accessed 12 February 2014).

Accepted 8 September 2014 
Appendix 1

Study No.

\section{Vaccination and Cervical Cancer Screening Project}

\section{COMPLETE THIS TOP SECTION BEFORE STARTING THE INTERVIEW}

Participant Study number:

Interviewer number:

Code for school attended by daughter:

Code for Site:

Date of Interview:

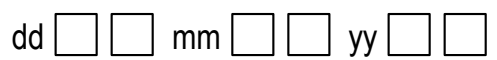

Introductory remarks

Hello, my name is ................................ Thank you for agreeing to this interview. I am going to ask you a few questions about your understanding of cervical cancer. It will take about 15 minutes. Your name and contact details that I write down here will be kept separate from the questionnaire so anything you tell me will be anonymous and be kept confidential. Thank you.

Participant name

Participant ID

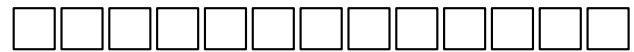

Participant Contact Numbers
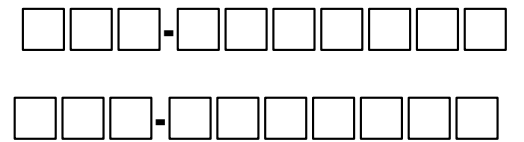

Daughter's Name

Daughter's ID/Birth date

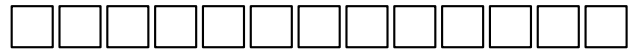

Instructions to the interviewer

- Circle the appropriate number/s or fill in the appropriate response.

- Follow skip patterns carefully. DO NOT read words in BOLD or CAPS OR ITALICS

- Use probes where necessary

- Circle the NOT MENTIONED options after completion of the interview, before signing completion of form

NB: FILL IN STUDY NUMBERS ON NEXT PAGES AND DETACH THIS FRONT PAGE FROM THE QUESTIONNAIRE AND STORE SEPARATELY 
Study No.

SECTION-1: Socio-Demographic Characteristics

READ: "To start I am going to ask you some questions about yourself"

No Questions and filters

Coding categories

Code Instructions

101 How old are you?

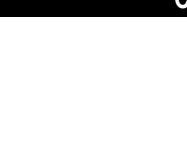

Age in years

Missing

102 What is the highest level of education you have completed?

CIRCLE ONLY ONE

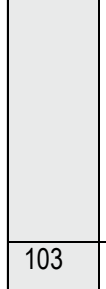

No formal schooling Grade 1/Sub A to Grade 7/Std 5

Grade 8/Std 6 to Grade 11/Std 9 Grade 12/Std 10

Diploma course

Technikon degree

University degree

Other course: Specify

$\left|\begin{array}{c|}{[1]} \\ -66\end{array}\right|$

READ RESPONSES ONE BY ONE

CIRCLE MORE THAN ONE IF NEEDED

Do you receive a grant

Do you receive financial support from other members of the family

Other: Specify

Other

No Income
Missing

1
2

2

3

4

6
7

7

Missing

$-66$

Yes

$\frac{\text { Yes }}{1}$

10

10

$-66$

SECTION-2: Use of Health Care Facilities

READ: Now I would like to ask you some questions about your use of health care facilities. Questions and filters Coding categories

\begin{tabular}{|l|l|l}
\hline 201 & $\begin{array}{l}\text { When did you last visit any health care } \\
\text { centre? }\end{array}$ & \\
CIRCLE ONLY ONE & \\
\hline 202 & $\begin{array}{l}\text { Why have you not visited a health care } \\
\text { centre for more than 5 years }\end{array}$ & \\
DO NOT READ RESPONSES \\
CIRCLE (1) IF MENTIONED \\
Probes: \\
Anything else?
\end{tabular} \mid




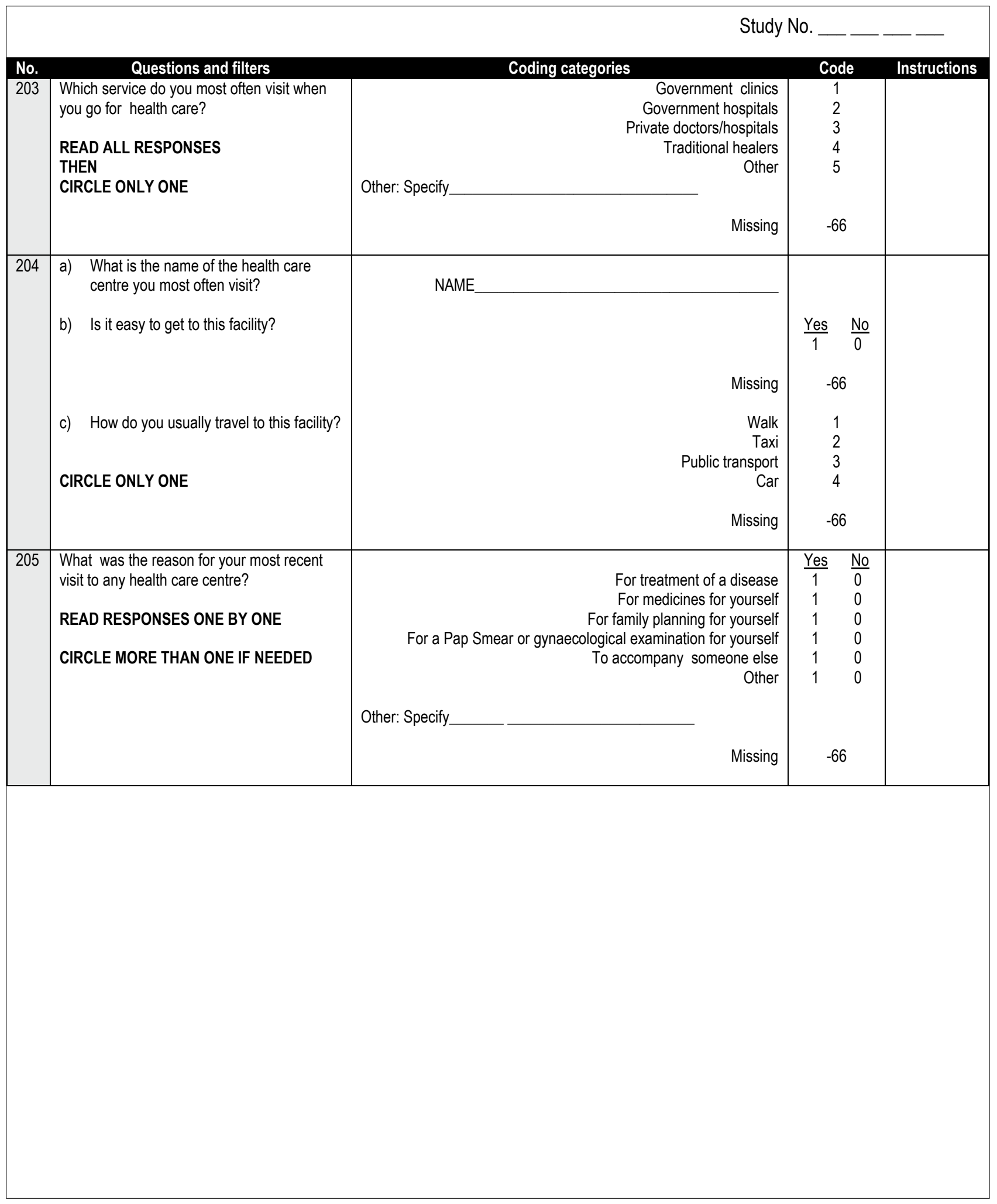


Study No.

SECTION-3: Knowledge of Pap Smears and cancer of the cervix

READ: "Now I would like to talk to you about cervical cancer and how to prevent it."

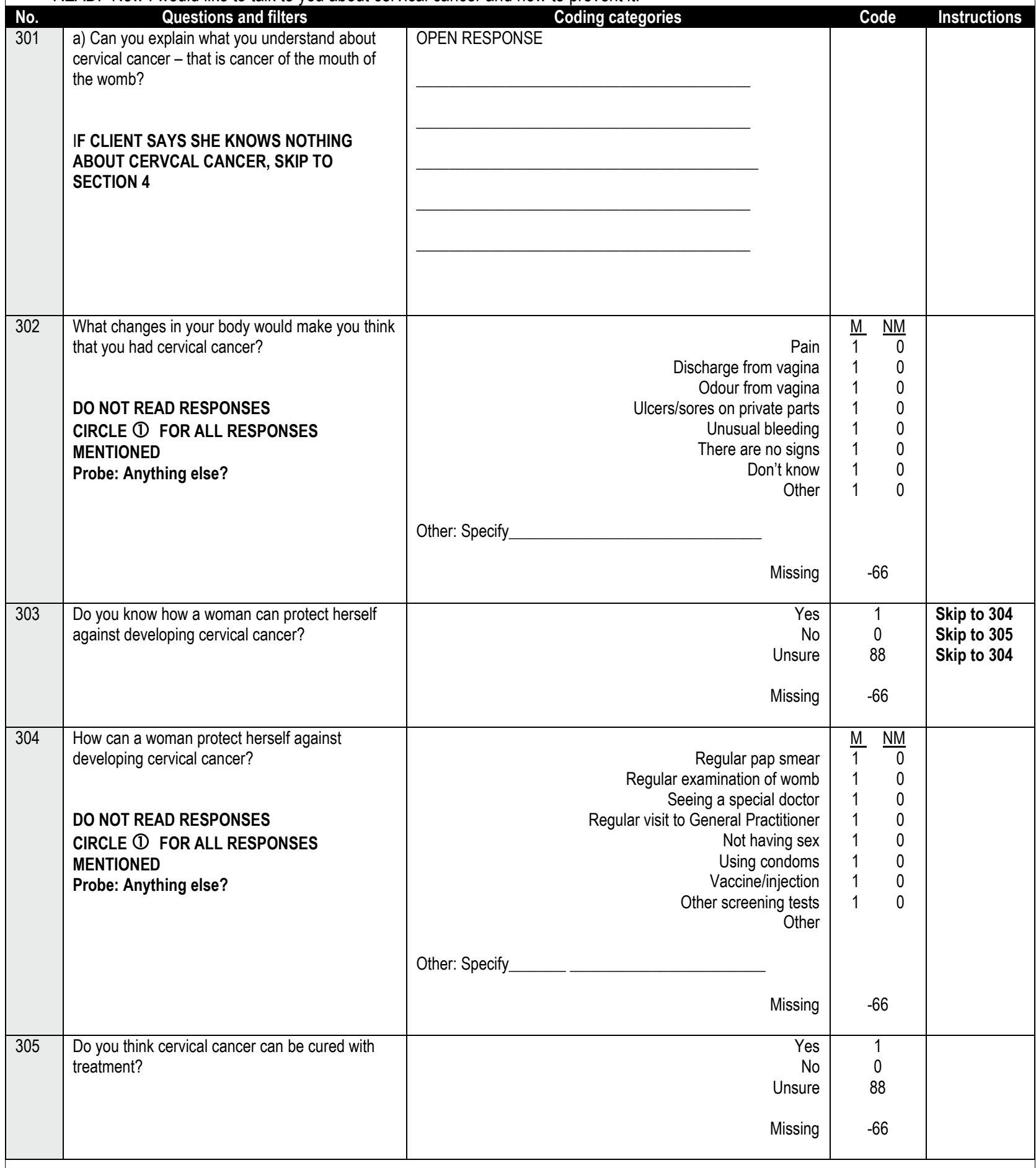


Study No.

SECTION-4: Cervix cancer screening History

READ: "Now I would like to ask you about any cervix cancer screening tests you may have had"

\begin{tabular}{|c|c|c|c|c|}
\hline No. & Questions and filters & Coding categories & Code & Instructions \\
\hline 401 & Have you ever had a test for cervical cancer? & $\begin{array}{r}\text { Yes } \\
\text { No } \\
\text { Unsure } \\
\text { Missing }\end{array}$ & $\begin{array}{c}1 \\
0 \\
88 \\
-66\end{array}$ & $\begin{array}{l}\text { Skip to } 402 \\
\text { Skip to } 403 \\
\text { Skip to } 501\end{array}$ \\
\hline 402 & $\begin{array}{l}\text { If YES } \\
\text { What test did you have? } \\
\text { DO NOT READ RESPONSES } \\
\text { CIRCLE (1) FOR ALL RESPONSES } \\
\text { MENTIONED } \\
\text { Probe: Anything else? }\end{array}$ & $\begin{array}{rr} & \begin{array}{r}\text { Pap smear } \\
\text { Vaginal Examination } \\
\text { Tampon test } \\
\text { Other }\end{array} \\
\text { Other: specify } & \\
& \text { Missing }\end{array}$ & $\begin{array}{lr}\frac{\mathrm{MM}}{1} & \frac{\mathrm{NM}}{0} \\
1 & 0 \\
1 & 0 \\
1 & 0 \\
& \\
& \\
& \\
& -66\end{array}$ & Skip to 404 \\
\hline 403 & $\begin{array}{l}\text { If NO } \\
\text { Why have you never had a test for cervical } \\
\text { cancer? } \\
\text { DO NOT READ RESPONSES } \\
\text { CIRCLE (1) FOR ALL RESPONSES } \\
\text { MENTIONED } \\
\text { Probe: } \\
\text { Anything else? }\end{array}$ & $\begin{array}{r}\text { Scared } \\
\text { Embarrassed } \\
\text { My partner wouldn't like it } \\
\text { I don't have the money } \\
\text { I don't like having these kinds of tests } \\
\text { I have never heard about this before } \\
\text { Didn't know where to go } \\
\text { Didn't think it would help me } \\
\text { Did not have a reason to go for one } \\
\text { Other }\end{array}$ & $\begin{array}{lr}\frac{\mathrm{M}}{\mathrm{M}} & \frac{\mathrm{NM}}{0} \\
1 & 0 \\
1 & 0 \\
1 & 0 \\
1 & 0 \\
1 & 0 \\
1 & 0 \\
1 & 0 \\
1 & 0 \\
1 & 0 \\
& \end{array}$ & Skip to 501 \\
\hline 404 & $\begin{array}{l}\text { How many years ago was your last test for cervical } \\
\text { cancer? } \\
\text { CIRCLE ONLY ONE }\end{array}$ & $\begin{array}{r}\text { Less than } 1 \text { year ago } \\
1-5 \text { years } \\
6-10 \text { years } \\
>10 \text { years ago } \\
\text { Don't know } \\
\text { Missing }\end{array}$ & $\begin{array}{c}1 \\
2 \\
3 \\
4 \\
88 \\
-66\end{array}$ & \\
\hline 405 & $\begin{array}{l}\text { What was the result of your last test? } \\
\text { CIRCLE ONLY ONE }\end{array}$ & $\begin{array}{r}\text { Normal } \\
\text { Abnormal } \\
\text { Don't know } \\
\text { Missing }\end{array}$ & $\begin{array}{c}1 \\
0 \\
88 \\
-66\end{array}$ & $\begin{array}{l}\text { Skip to } 501 \\
\text { Skip to } 406 \\
\text { Skip to } 501\end{array}$ \\
\hline 406 & $\begin{array}{l}\text { Did you have any treatment for this? } \\
\text { CIRCLE ONLY ONE }\end{array}$ & $\begin{array}{r}\text { Yes } \\
\text { No } \\
\text { Unsure } \\
\\
\text { Missing }\end{array}$ & $\begin{array}{c}1 \\
0 \\
88 \\
-66\end{array}$ & \\
\hline
\end{tabular}


Study No.

SECTION-5: Vaccination Knowledge and attitudes

READ: "Now I would like to ask you about your opinions about vaccination and cervical cancer"

\begin{tabular}{|c|c|c|c|c|}
\hline No. & Questions and filters & Coding categories & Code & Skip To \\
\hline 501 & $\begin{array}{l}\text { Have you ever heard of a vaccine or injection to } \\
\text { prevent cervical cancer? }\end{array}$ & $\begin{array}{r}\text { Yes } \\
\text { No } \\
\text { Unsure } \\
\text { Missing }\end{array}$ & $\begin{array}{c}1 \\
0 \\
88 \\
-66\end{array}$ & $\begin{array}{l}\text { Skip to } 502 \\
\text { Skip to } 503 \\
\text { Skip to } 503\end{array}$ \\
\hline 502 & $\begin{array}{l}\text { IF YES: Who is the vaccine or injection for? } \\
\text { DO NOT READ RESPONSES } \\
\text { CIRCLE (1) FOR ALL RESPONSES } \\
\text { MENTIONED } \\
\text { Probe: Anybody specific? }\end{array}$ & $\begin{array}{r}\begin{array}{r}\text { Women/girls only } \\
\text { Men and women/girls }\end{array} \\
\text { Women/girls under a certain age } \\
\text { Women/girls who have not had sexual intercourse yet } \\
\text { Don't know enough about it } \\
\text { Other }\end{array}$ & $\begin{array}{ll}\frac{\mathrm{M}}{1} & \frac{\mathrm{NM}}{0} \\
1 & 0 \\
1 & 0 \\
1 & 0 \\
1 & 0 \\
1 & 0\end{array}$ & \\
\hline 503 & $\begin{array}{l}\text { Do you think a vaccine to prevent cervical cancer } \\
\text { would be good to have? }\end{array}$ & $\begin{array}{r}\text { Yes } \\
\text { No } \\
\text { Unsure } \\
\text { Missing }\end{array}$ & $\begin{array}{c}1 \\
0 \\
88 \\
-66\end{array}$ & $\begin{array}{l}\text { Skip to } 505 \\
\text { Skip to } 504 \\
\text { Skip to } 504\end{array}$ \\
\hline 504 & $\begin{array}{l}\text { IF NO or unsure: } \\
\text { Why do you think it would not/ might not } \\
\text { be good to have a vaccination to prevent cervical } \\
\text { cancer? } \\
\text { End interview. Thank the client for her help and } \\
\text { ask: "Do you have any questions?" }\end{array}$ & OPEN RESPONSE & & \\
\hline 505 & $\begin{array}{l}\text { SAY: There is such a vaccine: } \\
\text { ASK: Would you advise primary school girls to } \\
\text { have it? } \\
\text { End interview. Thank the client for her help and } \\
\text { ask: "Do you have any questions?" }\end{array}$ & $\begin{array}{r}\text { Yes } \\
\text { No } \\
\text { Unsure } \\
\text { Missing }\end{array}$ & $\begin{array}{c}1 \\
0 \\
88 \\
-66\end{array}$ & \\
\hline
\end{tabular}

Signature of Interviewer (post-interview)

(Your signature verifies that you have reviewed the responses given by the interviewee, corrected any problems, and that ALL questions have a response marked.)

\section{INTERVIEWER: Is this survey complete? \\ $1=$ Complete}

2 = Incomplete

If not complete please give reasons: 


\section{VACCS Project - Second Interview}

SECTION-6: Knowledge of Pap Smears and cancer of the cervix

READ: "Now I would like to talk to you about cervical cancer and how to prevent it."

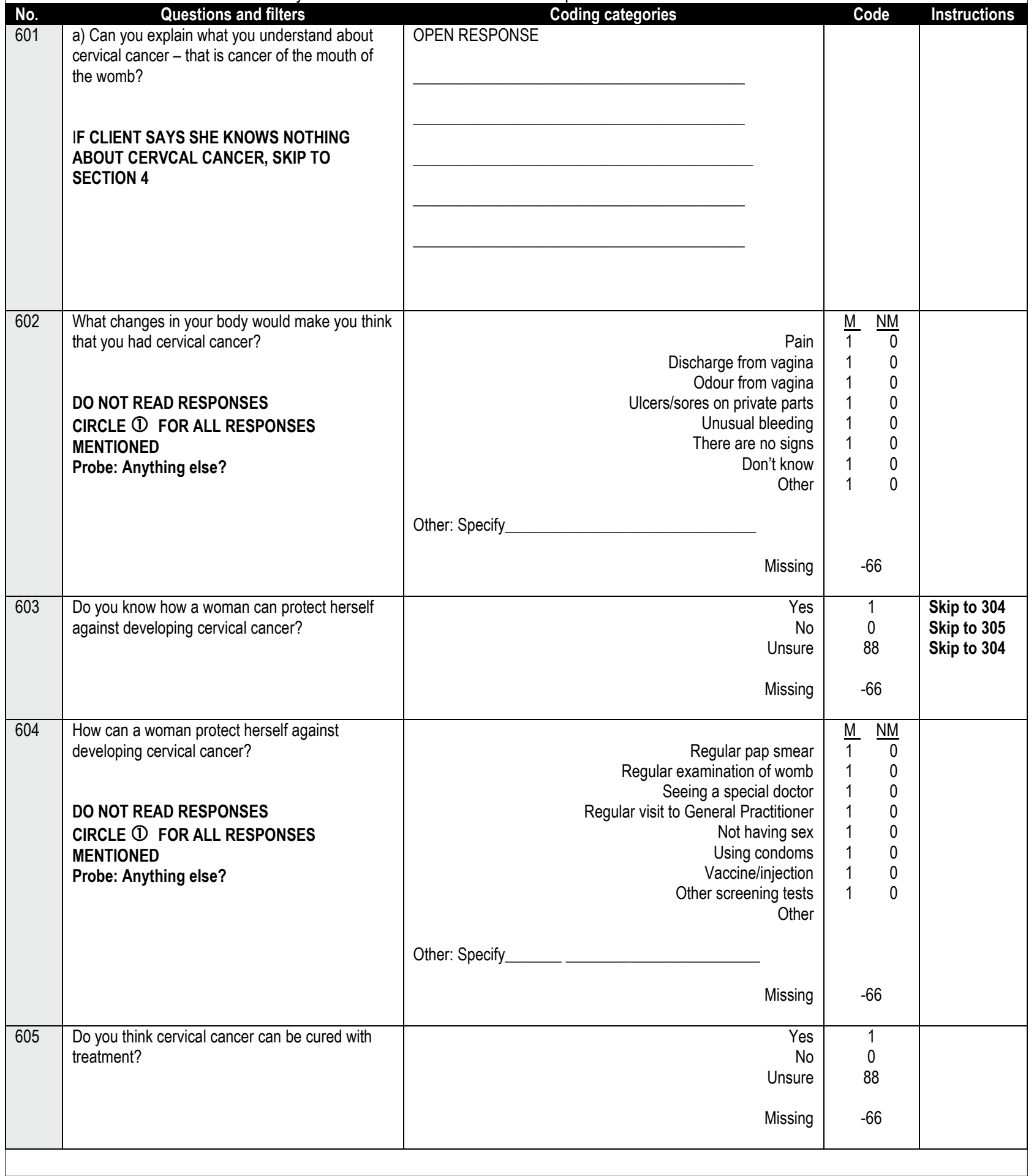


Study No.

SECTION-7: Cervix cancer screening History

READ: "Now I would like to ask you about any cervix cancer screening tests you may have had"

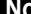
Questions and filters

Coding categories

701 Have you ever had a test for cervical cancer?

(2)

CIRCLE (1) FOR ALL RESPONSES

MENTIONED

Probe: Anything else?

703 If NO

Why have you never had a test for cervical

cancer?

DO NOT READ RESPONSES

CIRCLE (1) FOR ALL RESPONSES

MENTIONED

Probe:

Other: specify

Anything else?

't think it would help me

Did not have a reason to go for one

Other

Other specify

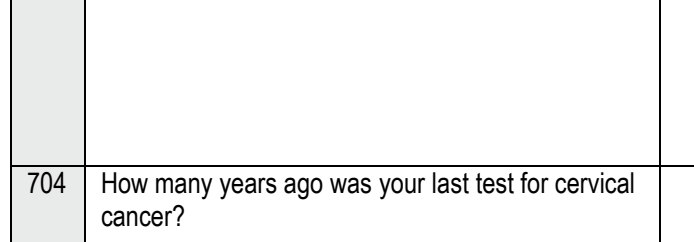

How many years ago was your last test for cervical

cancer?

CIRCLE ONLY ONE

\begin{tabular}{|l|l|} 
& \\
\hline 705 & What was the result of your last test? \\
& CIRCLE ONLY ONE \\
\hline 706 & Did you have any treatment for this? \\
& CIRCLE ONLY ONE \\
\hline
\end{tabular}

- I don't have the money

I don't like having these kinds of tests

I have never heard about this before

Examination

Other

sing

Scared

M

$\frac{M}{1} \quad$ NI
1
1

NM
0
0

0

10

Other specify
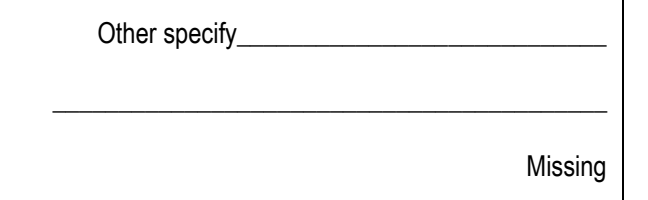
Study No.

SECTION-8: Vaccination Knowledge and attitudes

READ: "Now I would like to ask you about your opinions about vaccination and cervical cancer"

\begin{tabular}{|c|c|c|c|c|}
\hline No. & Questions and filters & Coding categories & Code & Skip To \\
\hline 801 & $\begin{array}{l}\text { Have you ever heard of a vaccine or injection to } \\
\text { prevent cervical cancer? }\end{array}$ & $\begin{array}{r}\text { Yes } \\
\text { No } \\
\text { Unsure } \\
\text { Missing }\end{array}$ & $\begin{array}{c}1 \\
0 \\
88 \\
-66\end{array}$ & $\begin{array}{l}\text { Skip to } 502 \\
\text { Skip to } 503 \\
\text { Skip to } 503\end{array}$ \\
\hline 802 & $\begin{array}{l}\text { IF YES: Who is the vaccine or injection for? } \\
\text { DO NOT READ RESPONSES } \\
\text { CIRCLE (1) FOR ALL RESPONSES } \\
\text { MENTIONED } \\
\text { Probe: Anybody specific? }\end{array}$ & $\begin{array}{r}\begin{array}{r}\text { Women/girls only } \\
\text { Men and women/girls } \\
\text { Women/girls under a certain age } \\
\text { Women/girls who have not had sexual intercourse yet } \\
\text { Don't know enough about it } \\
\text { Other }\end{array} \\
\end{array}$ & $\begin{array}{lr}\frac{\mathrm{M}}{1} & \frac{\mathrm{NM}}{0} \\
1 & 0 \\
1 & 0 \\
1 & 0 \\
1 & 0 \\
1 & 0\end{array}$ & \\
\hline 803 & $\begin{array}{l}\text { Do you think a vaccine to prevent cervical cancer } \\
\text { would be good to have? }\end{array}$ & $\begin{array}{r}\text { Yes } \\
\text { No } \\
\text { Unsure } \\
\text { Missing }\end{array}$ & $\begin{array}{c}1 \\
0 \\
88 \\
-66\end{array}$ & $\begin{array}{l}\text { Skip to } 505 \\
\text { Skip to } 504 \\
\text { Skip to } 504\end{array}$ \\
\hline 804 & $\begin{array}{l}\text { IF NO or unsure: } \\
\text { Why do you think it would not/ might not } \\
\text { be good to have a vaccination to prevent cervical } \\
\text { cancer? } \\
\text { End interview. Thank the client for her help and } \\
\text { ask: "Do you have any questions?" }\end{array}$ & OPEN RESPONSE & & \\
\hline 805 & $\begin{array}{l}\text { SAY: There is such a vaccine: } \\
\text { ASK: Would you advise primary school girls to } \\
\text { have it? } \\
\text { End interview. Thank the client for her help and } \\
\text { ask: "Do you have any questions?" }\end{array}$ & $\begin{array}{r}\text { Yes } \\
\text { No } \\
\text { Unsure } \\
\text { Missing }\end{array}$ & $\begin{array}{c}1 \\
0 \\
88 \\
-66\end{array}$ & \\
\hline
\end{tabular}

Signature of Interviewer (post-interview)

(Your signature verifies that you have reviewed the responses given by the interviewee, corrected any problems, and that ALL questions have a response marked.)

INTERVIEWER: Is this survey complete?

$$
\begin{aligned}
& 1=\text { Complete } \\
& 2=\text { Incomplete }
\end{aligned}
$$

If not complete please give reasons: 